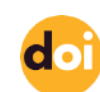

http://doi.org/10.22282/ojrs.2021.81

\title{
EXAMINATION OF THE PSYCHOLOGICAL ROBUSTNESS LEVELS OF ACTIVE ADOLESCENTS IN INDIVIDUAL AND TEAM SPORTS
}

Hayrettin GÜMÜŞDAĞ, Mehmet AYDOĞAN

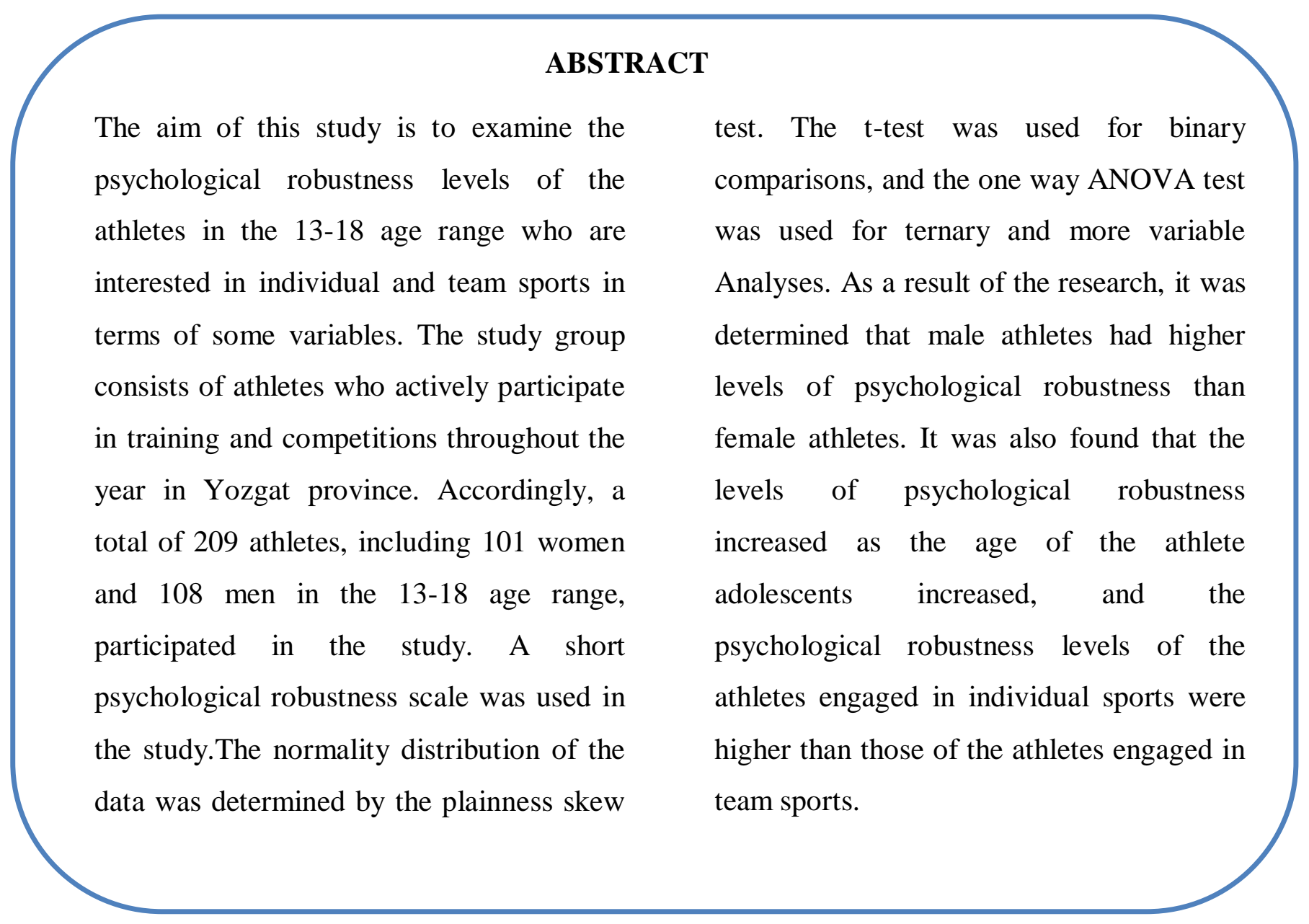

Key Words: Adolescent, Sports, Psychological Stability 


\section{INTRODUCTION}

The aim of this study is to examine the psychological robustness levels of adolescents who are professional athletes in different sports branches and to make suggestions to athletes who have low psychological robustness and to contribute to the field paper on increasing psychological robustness levels.

Psychological robustness is mentioned in the dictionary as the Turkish word 'resilience', which is an English concept. The word' Resilience 'is quoted in the Living English Dictionary as ' ability to throw back, resilience, quick recovery ${ }^{11}$. In Turkish English-Redhouse dictionary, the word' resilience 'has been translated into Turkish as" resilience, resilience, ability to heal quickly, strength to overcome difficulties and resilience ${ }^{14}$.

The history of the concept of psychological robustness is based on studies in the 1960s and 1970s to understand the course and severity of serious psychopathological conditions such as schizophrenia. Norman Garmezy, E. James Anthony and Michael Rutter's 1974 work pioneered the development of the concept of psychological robustness ${ }^{5}$. In recent years, in the development of psychopathology, the concept of psychological robustness, which is defined as positive adaptation in the face of a serious life challenge or trauma, has become increasingly important $^{12}$.

Psychological robustness is an extremely important concept for adolescents. High levels of psychological robustness during developmental periods will positively affect their future. Therefore, it is of utmost importance to examine the psychological robustness levels of adolescents.

Answers to the problems listed below will be searched within the research:

- Does the psychological robustness levels of the adolescents involved in the research differ according to the branches?

- Do the levels of psychological well-being of the adolescents involved in the study differ according to the welfare level of their families?

- Do the levels of psychological robustness of the adolescents involved in the study differ according to the gender variable? 


\section{MATERIAL AND METHOD}

\section{Model Of Research}

In this study, a screening model was used to examine the psychological robustness levels of adolescents who are athletes in different sports branches. This model is a scan of the entire universe or sample taken from it in order to reach a general judgment about the universe in a universe of many elements ${ }^{16}$.

\section{Study Group}

An average of 209 athletes from different types of branches participated in the study group, actively participating in training and competitions throughout the year.

Table 1. Demographics of the Working Group

\begin{tabular}{llll}
\hline \multirow{2}{*}{ Gender } & & f & \% \\
\cline { 2 - 4 } & Man & 101 & 48,4 \\
& Woman & 108 & 51,6 \\
& Total & 209 & 100 \\
\hline Age & 13-14 Age & 62 & 30 \\
& 15-16 Age & 75 & 36 \\
& 17-18 Age & 72 & 34 \\
\hline Branch & İndividual Sports & 110 & 52,7 \\
& Team Sport & 99 & 47,3
\end{tabular}

$48.4 \%$ of the students who participated in the study were male students and $51.6 \%$ were female students. $230 \%$ of the students are in the $13-14$ years old, $36 \%$ are in the $15-16$ years old and $34 \%$ are in the $17-18$ years old range. In addition, $52.7 \%$ of the participants were involved in individual sports and $47.3 \%$ were involved in team sports. 


\section{Data Colllection Tools}

Short psychological robustness scale was developed to measure the potential and psychological robustness of individuals to recover themselves. The scale was developed by Smith et all $^{17}(2008)$ and adapted into Turkish by Doğan ${ }^{18}$ (2013). This scale, consisting of 6 items of 5 ' li likert type, is a measurement tool in the form of self-notification. It is scored in the form of" not fit at all "(1)," Not Fit "(2)," somewhat fit" (3), Fit "(4)," fully fit " (5). These 6 items are 2, 4 and 6.the items are coded backwards but must be translated first in the scoring key. High scores after this procedure show a high level of psychological robustness, while low scores indicate a low level of psychological robustness.

Matter factor loads of the scale .With .63 .It ranges from .79. Item total correlation values of the scale with .49 .It is among 66. Internal consistency coefficient of the scale .It has been identified as .83 .

In addition, the Personal Information Form developed by the researcher was also applied to the working group within the research.

\section{Analysis of the Data}

For the purpose of the research, the data collected for the sub-problems for which answers are sought were first processed into the data coding form. All 209 data were included in the study. Statistical analyses were then applied on the data transferred to the SPSS 24.0 package program.

The frequencies values are presented in statistical representations of the data. Skewness and kurtosis values with the test which is showing normal distribution of data was tested for normal distribution parametric tests were applied is shown. The T test and one way ANOVA test were used for the age range. 
Tablo 2. Normality distributions of data

\begin{tabular}{lccc}
\hline & N & Skewness & Kurtosis \\
\hline Psychological Robustness & 209 & -352 &, 628 \\
Scale & & & \\
\hline
\end{tabular}

In Table 2 , the points were found to be in the range \pm 2 . Cooper-Cutting describes skewness and kurtosis values in the range of \pm 2 as an appropriate case for normality, while Büyüköztürk interprets these values in the range of \pm 1 as not deviating from normality.

In the study, it was decided to apply paremetric statistical techniques as it was seen that the skew-flattness values of the scores were not extreme levels, they were in the range of \pm 2 and there were no extreme deviations in the normal distribution curves.

\section{FINDINGS}

Do the levels of psychological robustness of the adolescents involved in the study differ according to the type of branch?

Table 3. Results of the analysis between the psychological robustness levels and branch types of the athletes participating in the study

\begin{tabular}{|c|c|c|c|c|c|}
\hline & Branch Type & $\mathbf{n}$ & $\mathbf{X} \pm \mathbf{S s}$ & $t$ & $\mathbf{p}$ \\
\hline Psychological & İndividual & 110 & $17,04 \pm, 8,28$ & 3,458 & $\mathbf{0 , 0 3 *}$ \\
\hline Robustness & Sports & & & & \\
\hline Scale & Team Sport & 99 & $13,05 \pm 7,25$ & & \\
\hline
\end{tabular}


Do the psychological robustness levels and age ranges of the adolescents involved in the study differ significantly?

Table 4. Results of the analysis between the psychological robustness levels and age ranges of the athletes participating in the study

\begin{tabular}{|c|c|c|c|c|c|c|}
\hline \multicolumn{2}{|r|}{ Age } & $\bar{n}$ & $\mathrm{X} \pm \mathrm{Ss}$ & $\overline{\mathbf{F}}$ & $\mathbf{P}$ & Tukey \\
\hline Psychological & 13-14 Age ${ }^{1}$ & 62 & $11,17 \pm, 5,31$ & & & \\
\hline Robustness & 15-16 Age $^{2}$ & 75 & $12,52 \pm 5,24$ & 8,037 & $0,000^{*}$ & $1-$ \\
\hline \multirow[t]{2}{*}{ Scale } & 17-18 Age $^{3}$ & & $15,13 \pm 4,23$ & & $3 *$ & \\
\hline & & 72 & & & & \\
\hline
\end{tabular}

According to Table 4, statistical analyses conducted between the age variable and psychological robustness levels of the athletes participating in the study showed that there was a significant difference in the alpha level of $\mathrm{P}<0.05$ between 13-14 years and 17-18 years $(\mathrm{p}=0.000)$. The results of the analysis showed that the significant difference was due to the age range of 17-18.

Do the levels of psychological robustness of the adolescents involved in the study differ according to the gender variable?

Table 5. Results of analysis between psychological robustness levels and gender of the athletes participating in the study

$\begin{array}{lllll}\text { Gender } & \mathbf{N} & \mathrm{X} \pm \mathrm{Ss} & \mathbf{t} & \mathbf{p}\end{array}$

\begin{tabular}{llllll}
\hline Psychological & Man & 101 & $19,27 \pm 8,45$ & 2,207 & $\mathbf{0 , 0 2 *}$
\end{tabular}

Robustness Scale Woman $108 \quad 13,49 \pm 7,39$

According to Table 5, it was determined that there was a significant difference in the alpha level of $\mathrm{p}<0.05(\mathrm{p}=0.02)$ between the gender variable and psychological robustness levels 
of the athletes participating in the study. The results of the analysis showed that the significant difference was due to men.

\section{DISCUSSION AND CONCLUSION}

Of adolescents surveyed psychological robustness levels differ by type of industry, whether as a result of statistical analysis performed, individual team of athletes the level of psychological robustness $(17,04 \pm, 8,28)$, team sports athletes who level of psychological robustness $(13,05 \pm 7.25)$ are high, and between them $\mathrm{p}<0.05$ were found significant differences at the alpha level $(\mathrm{p}=0.03)$.

The literature is examined, the study examines the relationship between levels of psychological robustness with the type of athletes that any branch without the knowledge of the research literature in the light of this information, and is thought to contribute to subsequent works.

Statistical analysis of the age variable and psychological robustness levels of the athletes involved in the study found that there was a significant difference in alpha level of $\mathrm{P}<0.05$ between 13-14 years and 17-18 years $(\mathrm{p}=0.000)$. The results of the analysis showed that the significant difference was due to the age range of 17-18.

As a result, the research showed that as the age variable increases, the level of psychological robustness also increases. Gooding, Hurst, Johnson and Tarrier ${ }^{7}$ concluded in their research that the psychological endurance levels of the elderly were higher than those of the young. Erim and Küçük $(2017)^{6}$ examidoğaned the psychological robustness of female national boxers and determined that A national athletes had higher psychological endurance than young and Star national athletes. However, a study by Atik $^{1}$ (2013) found a statistically significant and positive relationship between psychological robustness and age variable. In the current study, it was concluded that the increase in psychological robustness as age increases, the age variable and the level of psychological robustness are paralleled. The increasing level of psychological robustness as age progresses can be explained by the fact that, as you gain experience over time, challenging life events can be overcome more easily. 
A study on Judo athletes by Çutuk, Beyleroğlu, Hazar, Akkuş-Çutuk and Bezci ${ }^{3}$ (2017) found a negative correlation between participants ' psychological endurance levels and their age. This study contrasts with the research conducted.,

Statistical analysis of the gender variable and psychological robustness levels of the athletes participating in the study found that there was a significant difference in the alpha level of $p<0.05$ ( $p=0.02$ ). The results of the analysis showed that the significant difference was due to men.

Research by Saka and Ceylan ${ }^{15}$ (2018) found that female adolescents had significantly higher psychological endurance scores than male adolescents. Çutuk, Beyleroğlu, Hazar, Akkuş Çutuk and Bezci ${ }^{3}$ (2017) have determined that female judoists have significantly higher psychological endurance than male judoists. The results of these studies differ from the current research results. Desai ${ }^{4}$ (2017)'s research concluded that male participants had significantly higher scores than female participants. Oktan ${ }^{13}$ (2008) and Koç-Yildirim ${ }^{9}$ (2014) have found that there is a significant difference between psychological robustness and gender. These studies support the results from the research.

Çelik $^{2}$ (2018) determined in his research that there was no significant difference between male and female athletes in overall psychological endurance level. Kumar, Singh and Mitra (2016) concluded that the participants ' mental endurance levels did not differ by gender in their research. Hosseini and Besharat ${ }^{8}$ (2010) stated that there was no significant difference in the psychological robustness levels of male and female athletes. These studies contradict our research.

\section{REFERENCES}

1. Atik, E. L. (2013). Liseli ergenlerde bağlanma stilleri ve psikolojik sağlamlık düzeyleri arasındaki ilişkide öz-yansıtma ve içgörünün rolü. Yayınlanmamış Yüksek Lisans Tezi. İstanbul Bilim Üniversitesi Sosyal Bilimler Enstitüsü, İstanbul.

2. Çelik O.B. 2018. Sporcu Ergenlerde Psikolojik Sağlamlık. CBÜ Beden Eğitimi ve Spor Bilimleri Dergisi. 2,296-303. 
3. Çutuk, S., Beyleroğlu, M., Hazar, M., Akkuş Çutuk, Z. ve Bezci, Ş. (2017). Judo sporcularının psikolojik dayanıklılık düzeyleri ile kaygı düzeyleri arasındaki ilişkinin incelenmesi. Niğde Üniversitesi Beden Eğitimi ve Spor Bilimleri Dergisi, 11(1), 109117.

4. Desai, R.B. (2017). Psychological hardiness among college students. The International Journal of Indian Psychology, 4(3), 80-84.

5. Doğan, T.,Sapmaz, F., Ve Çötok, N. A. 2013. “Özeleştiri Ve Mutluluk”, Kastamonu Eğitim Dergisi, Ss.391-400.

6. Erim, V. ve Küçük H. (2017). Farklı Kategorideki Kadın Milli Boksörlerin Psikolojik Dayanıklılıklarının Karşılaştırılması. Kastamonu Eğitim Dergisi, 25(1), 147 - 154

7. Gooding, P.A., Hurst, A., Johnson, J. \& Tarrier, N. (2012). Psychological resilience in young and older adults. International Journal of Geriatric Psychiatry, 27(3), 262-270

8. Hosseini, S.A. \& Besharat, M.A. (2010). Relation of resilience with sport achievement and mental health in a sample of athletes. Procedia - Social and Behavioral Sciences, 5, 633-638.

9. Koç-Yıldırım, P. (2014). Ergenlerde psikolojik dayanıklılık ile benlik kurgusu arasındaki ilişkinin incelenmesi. Yayınlanmamış yüksek lisans tezi, Marmara Üniversitesi Eğitim Bilimleri Enstitüsü.

10. Kumar, S., Singh, N.S. \& Mitra, S. (2016). Comparison of mental toughness between male and female volleyball players of 12th south Asian games. International Journal of Applied Research, 2(6), 268-270.

11. Living English Dictionary. 2013. 'Resilient'. K1lavuz Yayınları, İstanbul

12. Luthar, S. S. 2006. Resilience İn Development: A Synthesis Of Research Across Five Decades. (D. C. Cohen, Dü.) Development Psycopathology: Risk, Disorder And Adaptation (Second Edition,

13. Oktan, V. (2008). Üniversite sınavına hazırlanan ergenlerin psikolojik sağlamlıklarının çeşitli değişkenlere göre incelenmesi. Yayınlanmamış Doktora Tezi. Karadeniz Teknik Üniversitesi Sosyal Bilimler Enstitüsü, Trabzon.

14. Redhouse Resimli Sözlük. 2008. 'Resilience'. Sev Matbaacılık, İstanbul.

15. Saka, A. ve Ceylan, Ş. (2018). Ergenlerin psikolojik dayanıklılık düzeylerinin aile yapılarına göre incelenmesi. Eğitim ve Toplum Araştırmaları Dergisi, 5(1), 68-86. 
16. Karasar N, 2004. Bilimsel Araştırma Yöntemi, Nobel Yayınları, Ankara.

17. Smith, B. W., Tooley, E. M., Christopher, P., \& Kay, V. S. (2010). Resilience as the ability to bounce back: A neglected personal resource?. Journal of Positive Psychology, $5,166-176$.

18. Doğan T. (2015). Adaptation of the Brief Resilience Scale into Turkish: A validity and reliability study. The Journal of Happiness \& Well-Being, 3(1), 93-102 